\title{
Social work and other helping professions in the process of professionalisation. The specificity of Poland after 1989 from the sociology of professions' perspective
}

\section{Abstract}

Helping occupations are an integrated category for all specialists delivering social services. Thera are two main dimensions of professionalism in delivering services: (1) technical aspect associated with the accumulation of specialized knowledge about services, and (2) normative aspect related to the service ideal. Sociology of professions considers helping occupations as semi-professions: occupations under the process of professionalisation. In Western Europe helping occupations emerged after Industrial Revolution and have been professionalised within the frame of modern welfare states. In Poland professionalisation of helping occupations was frozen during fifty years of communism and has accelerated under the transformation and modernisation of the last three decades. Like in all EU countries variety of helping specialist have reached the status of regulated occupations. Specificity of the Polish professionalisation path is related to: (1) unsuccessful attempts to

1 Correspondence: Wydział Stosowanych Nauk Społecznych i Resocjalizacji — Instytut Stosowanych Nauk Społecznych, University of Warsaw, Nowy Świat 69, 00-046, Warszawa, Polska, author's email address: marek.rymsza@uw.edu.pl 
make social work a reference category for all helping practices, (2) construction of a legal category of the public trust professions open only for a smaller part of helping specialists, (3) ongoing processes of differentiation of assistance practices and fragmentation of social services. The Author argues that in the upcoming years public policy should be implemented to create a new order of helping professions and social services.

Key words: helping (semi-)professions, professionalisation, social work, service ideal, welfare state

\section{Professionalisation of occupations as an element of the development of welfare states - processual approach}

Social service is (1) non-monetary and intangible support, (2) provided by an adequately prepared specialist (3) in direct contact with the receiver (4) as part of the helping relationship ${ }^{2}$. The term service carries the connotation of the professional nature of support having two basic dimensions: technical and normative (Wilensky, 1964, p. 138). It is precisely because of these two equivalent dimensions of professional service support that we translate the English term social service into Polish in two ways: as ustuga spoteczna and stuzba spoteczna. Each of the Polish equivalents emphasizes one of the two basic dimensions of professionalism: ustuga spoteczna - the technical dimension, and stużba spoteczna - the normative dimension.

Occupations whose representatives meet the professionalism criterion in both dimensions: technical and normative are called professions (Carr-Saunders, 1955, p. 280). The technical aspect here is associated with the accumulation of specialised knowledge about a specific occupation, and in the case of profession this knowledge acquires the status of academic knowledge. Thus, access to a profession requires a university degree in a specific field. The normative aspect is related to the clarifying occupational deontology. Norms that form it are binding as a code of professional ethics, which is guarded by a representative professional association. The mechanism of professional control of ethical standards may be strengthened by the requirement of belonging to the professional association of all active representatives of a given profession. The association then becomes professional self-government.

Sociologists analysing the evolution of social policy in democratic countries with a market economy, situate the process of professionalisation of occupations and services - including helping specialists and social services - in the context of the development of the welfare state infrastructure within the industrial society:

${ }^{2}$ Definition proposed by the Author. The term social services is defined in different ways. Wide definitions cover almost all public administration activities undertaken to meet peoples' needs, including cash benefits. But there is tendency to narrow down meaning of social services (Morel, 2010, p. 1300) as it is proposed in this paper. 
"The welfare state collectivizes the professions and professionalizes social services" (Marshall, 1950, p. 10);

"The increase in the number of professionals and the growth of professionalism has been generally accepted by social scientists as a major if not a defining characteristic of industrial societies" (Johnson, 1972, p. 9).

In the first stage of industrialisation, occupations of the industrial era emerged, which were distinguished by the performance of a specific trade under an employment relationship, for a pre-determined remuneration: "Industrialisation transforms the nature of the labour force: the 'self-employed' - the farmers, craftmen and the like - are replaced by workers 'employed' for a wage" (Mishra, 1981, p. 40). At the same time, their differentiation turned out to be disproportionately larger than the system of craft guilds from the pre-industrial period and lay at the root of corporate labour relations and organic solidarity as the foundation of a new collective order (Durkheim, 1960).

In functional terms, the professionalisation of occupations is the crowning achievement of the labour market organization after the industrial revolution, based on the social division of labour: "Professional occupations could be regarded as a unique product of the division of labour in society" (Johnson, 1972, p. 10). Professionalising occupations somewhat resembled traditional professions, shaped before the Industrial Revolution, and referred to as liberal professions or established professions; at the same time, as their development evolved, so did the understanding of the profession (Engel \& Hall, 1973, p. 85, table 1). As noted by Alexander M. Carr-Saunders, some of these occupations had acquired the status of new professions over time, and a prestige almost equal to established professions; for example architects (Carr-Saunders, 1955, p. 281). For other occupations, the status achievable through professionalisation would be the status of a semi-profession; in the typology cited (ibid.) these are medical and medicine-related professions such as nurses, midwives, pharmacists, opticians which do not match the prestige of medical doctors and have a somewhat auxiliary function. Researchers also include social welfare occupations in this group (Toren, 1969). Finally, the fourth category of occupations distinguished by Carr-Saunders are the would be professions, which are hindered in full professionalisation by too much advanced business, i.e. orientation to maximise the benefits of professional activity as part of the market game of here and now. These are all kinds of managerial occupations such as sales, transport and administration specialists (Carr-Saunders, 1955, p. 281).

The popularity of the fourfold typology of the profession: established professions, new professions, semi-professions, would be professions, cited in the literature in the classic version of Carr-Saunders or in modified versions, illustrates how important the finding for the development of sociology of professions ${ }^{3}$ has been the observation, that

3 In the Anglo-Saxon countries, we may identify sociology of professions as a separate sociological sub-discipline (Barber, 1963; Johnson, 1972; Collins, 1990). In Poland, studies focused on professionalisation are developed under the umbrella of sociology of work or sociology of occupations (Łuczyńska, 2013, p. 15). 
(1) the professionalism of professional activity is a graduated feature and that (2) there are limits to professionalism: different for different occupations. Harald Wilensky and Charles Lebeaux put it this way:

"(1) The job of the professional is technical. (2) The professional man adheres to a set of professional norms. The degree to which an occupation fits these criteria is the degree of its professionalisation." (Wilensky \& Lebeaux, 1965, p. 284).

Scientists tried to operationalise the status of achieving professionalism, indicating specific necessary elements. Box 1 shows that in theoretical conceptualizations the professionalisation of occupations is not only gradual, but also a multi-faceted process, with most aspects distinguished by researchers inscribed in two basic dimensions of professionalism: technical $(\mathrm{T})$ or normative $(\mathrm{N})$.

\section{Box 1. Attributes of the profession: selected conceptualisations}

\section{Bernard Barber's four essential attributes of the professional behaviour}

(1) A high degree of generalised and systemic knowledge (T);

(2) Primary orientation to the community interest rather than to individual self-interest $(\mathrm{N})$;

(3) A high degree of self-control of behaviour through code of ethics internalized in the process of work socialisation and through voluntary associations organized and operated by the work specialists themselves $(\mathrm{N})$;

(4) A system of reward (monetary and honorary) $(\mathrm{T} / \mathrm{N})$.

Source: Barber, 1965.

\section{Ernest Greenwood's five components of the ideal type of profession}

(1) A basis of systemic theory (T);

(2) Authority recognised by the clientele $(\mathrm{N})$;

(3) Broader community sanction and approval of the authority $(\mathrm{N})$;

(4) A code of ethics regulating relationship professional - client $(\mathrm{N})$;

(5) A professional culture sustained by formal professional accounts $(\mathrm{T} / \mathrm{N})$.

Source: Greenwood, 1957, pp. 45-55.

\section{Harold Wilensky's five components of the professionalisation process}

(1) start doing full time the thing that needs doing (T);

(2) establishment of a training school (T);

(3) combine to form a professional association $(\mathrm{T} / \mathrm{N})$;

(4) political agitation in order to win the support of law (T/N);

(5) emphasize the service ideal (...) in a formal code of ethics $(\mathrm{N})$.

Source: Wilensky, 1964, pp. 142-145.

Key: $\mathrm{T}$ - technical attribute; $\mathrm{N}$ - normative attribute; $\mathrm{T} / \mathrm{N}$ - complex attribute

Collation of concepts and classification of attributes by Author. 
Wilensky's proposition is the most far-reaching in terms of exploration, because in his view the distinguished aspects of professionalisation are at the same time the subsequent stages of the process of emerging professions and as such set the framework and course of the natural history of professionalisation:

"there is a typical process by which the established professions have arrived: men begin doing the work full time and stake out a jurisdiction; the early masters of the technique or adherents of the movement become concerned about standards of training and practice and set up a training school, which, if not lodged in universities at the outset, makes academic connections with two or three decades; the teachers and activists then achieve success in promoting more effective organization, first local, then national - through either the transformation of an existing occupational association or the creation of a new one. Toward the end, legal protection of the monopoly of skill appears; at the end, a formal code of ethics is adopted." (Wilensky, 1964, pp. 145-146).

Commentators point out that the natural histories of specific professions reconstructed by researchers usually differ from the cited description, which means that the sequence of events drawn by Wilensky does not meet the criterion of typicality. Natural history of professionalisation is not so much a historically documented sequence of events, but an analytical frame resembling natural history of the emergence of a social problem in the approach of Richard Fuller and Richard Myers (1941). This frame (1) allows the organisation of data on the process of professionalisation by distinguishing both specific aspects and phases of this process. At the same time (2) it exposes endogenous conditions of the dynamics of the professionalisation process. Professions rather become than are established, their emergence is a social process, and legal regulations or administrative decisions usually only confirm achievement of a certain stage of professionalisation.

Wilensky used the proposed analytical framework not only to interpret successful collective actions, but also to explain failures on the path of professionalisation. He argued that for an occupation to become a recognized profession, it must be professionalized in all indicated aspects, and this is not always possible. Some of the processes of professionalisation stop somewhat halfway. There are occupational groups that accept the semi-profession status; others try to unblock or accelerate the professionalisation process. Wilensky pointed to the dysfunction of professionalisation 'by force'. He noticed the depletion of the development logic of the welfare state, in which a growing number of occupational groups are undertaking efforts to obtain the status of a profession, doomed to fail. The article, in which he summarized his research on professionalisation, is suggestively entitled Professionalization of Everyone? (Wilensky, 1964). Randall Collins considered this publication a synthesis of not only Wilensky's achievements, but the entire functional-structural school, whose activity he called the classical period in sociology of professions (Collins, 1990, p. 13).

The observations of functionalist Wilensky were developed as part of the revisionist wave - the functional paradigm critical of the theory of social conflict, which includes Collins (1990, p. 13-15). The school of social conflict emphasized that the catalyst for 
professionalisation of occupations is the pursuit of broadening the field of self-benefit and power. First of all, there are elements of competition among occupations as part of a specific professions market (Goode, 1969, p. 269-274), where obtaining the status of a profession involves material and symbolic privileges, the most important of which is the possibility of monopolising the provision of services of a certain type (Collins, 1990, p. 18-21). Secondly, it is about the power of specialists over clients (Johnson, 1972, p. 41).

In terms of the theory of social conflict, the barriers and boundaries of professionalisation are therefore different than in terms of the functional school. This is no longer an unrealistic aspiration (Etzioni, 1969, VI) resulting from the utopian assumption that sooner or later every occupation will be able to meet the demanding requirements of the profession. The finding is that the requirements of professionalisation are dictated not so much by the public interest as functionalists assumed, but by the interests of the professionals themselves. At the same time, this market game of group interests triggers self-organisation also on the clients' side, which results in professional consumer organizations (Bertilsson, 1990, p. 131).

The school of social conflict also attached importance to analysing who controls whom. What for functionalists was a manifestation of the protection of consensual solutions and common values, for social conflict theorists appeared to be control by the elites, beneficial to their group interests (George \& Wilding, 1992, pp. 6-7). This control can take various forms and be anchored differently. Arlene Daniels (1973, pp. 42-54) pointed to the power of ethical codes, control over recruitment and certification, mandates of professional review boards. Terence Johnson, in turn (1972, pp. 41-47), distinguished three basic types of occupational control: collegiate control, patronage/client control, mediative control.

The profile of analyses proposed by theoreticians of social conflict is now being continued as part of the third generation of sociology of professions. Representatives of the critical analysis, focus their interests on the distribution of power and prestige through professionalisation, taking into account such socio-cultural variables as gender, race, ethnicity (Ming-Cheng, 2005).

\section{From relief investigators through social welfare occupations to helping semi-professions}

Liberal professions are a model for established professions. The literature lists three classical liberal professions that date back to pre-modern times: a doctor, a lawyer and a priest. Next — but here, there is no full agreement among researchers - another three model professions are indicated: engineer, architect and academic teacher. They achieved high prestige and social recognition later and are therefore recognized as representative examples of new professions.

Helping occupations have entered the path of professionalisation and are included in the group of semi-professions or aspiration professions. In Europe, they reached the status of regulated occupations, which means that formal qualifications are required for their practise; for some of them vocational education is sufficient, but certain fields require 
specialised university education (Kantowicz, 2000). Helping occupations have developed their ethical codes (Kaczyńska, 2010) and usually they have more or less representative professional associations. However, these occupations generally do not obtain the status of full professions.

Helping occupations in a wider group of occupations in the process of professionalisation are distinguished by three features:

(1) strong ethical orientation to help the weak and the those in need, which is reflected in the embedding of frontline work in the so-called helping relationship;

(2) a tendency to routinize assistance activities through the use of formal criteria to select those eligible for support and administrative procedures for providing assistance, which leads to combining assistance with social control;

(3) embedding assistance in the welfare state infrastructure, and in particular in social welfare facilities.

Helping occupations entered the path of professionalisation due to their strong normative element - the orientation towards helping those in need, which Wilensky (1964) described as service ideal. Service ideal sets a normative profile of all helping and assistant activities. This normative orientation is not only related to personal disposition of helpers, but has become shrouded in constantly developed scientific theory of welfare created on the border between ethics, philosophy and sociology (Barry, 1999; Goodin, 1988; Pinker, 1979; Wilding, 2010). As Joyce Warham argues, welfare theory is both (i) a normative foundation for social services and thus occupational deontology of helping professions that provide them ("primary function of social services is to promote welfare" - Warham, 1970, p. 44), and (ii) the axiological foundation of the welfare state concept ("The welfare state may be regarded as an ideological concept... the nature of the formal role assumed by the state is the promotion of welfare" - ibid., p. 58).

Service ideal determines that the proven methodology of helping creates instruments for effectively realizing what is ethically right. The relationship between the normative and technical aspects of professionalism is exactly the opposite here than in the case of an engineer, where normative principles are treated instrumentally and serve to create conditions for the specialist to implement technical solutions that are safe for the specialist, as long as they are efficient and increase efficacy.

The barrier of professionalisation is also different in the case of helping occupations than in the case of technical occupations, which are pushed to the professionalisation path by the growing technical efficiency related to developing the methodology of effective performance of the trade, but where the service ideal is missing, and the tendency to mercantilisation is strong. At the same time, as Wilensky points out, the service ideal of helping occupations significantly reduces the possibilities of technical professionalisation. It is difficult to distinguish competent assistance from social support based on voluntary engagement, which has an equally strong service orientation and can be effective, although the objectified methodology is at the in statu nescendi stage. 
The development of helping occupations, especially social work, took place during the period of building the welfare state within the industrial society framework. Wilensky and Lebeaux described how social workers in the United States became peculiar welfare state agents, caring for the well-being of citizens and employed in various institutions: in hospitals, schools, social welfare agencies, rehabilitation facilities, etc. At the same time, social work was not one new-born assistance profession, but an entire range of social welfare occupations and specialisations, including psychiatric social work, school social work, child social work, medical social work, teaching social work, group work, community organisation, work with adult offenders, family services (Wilensky \& Lebeaux, 1965, p. 292, table 9). All these helping specialities were distinguished by professionalisation through the development of the specific methodology of help from the pre-professional stage, when those providing help were referred to as relief investigators or caseworkers (Wilensky, 1964, p. 144).

An important aspect of professionalisation through institutionalisation - the process of settling the professional activity of helpers in facilities creating the welfare state infrastructure - was the progressing medicalisation of helping occupations in the 20th century. According to Talcott Parsons (2001, pp. 428-479), the medical profession was the benchmark for all helping specialists. In Parson's approach, the medical profession stood out by combining three pro-development components: (1) high prestige of the recognised liberal profession with well-established methodology and vocational deontology, (2) rationality of practice - professional practice was based on scientific knowledge accumulated in medical university faculties, and (3) ability to use modern high technology in providing services.

In Parsons' eyes, medical doctors were those professionals from the pre-industrial era, who fully adapted to the conditions of modern society after the industrial revolution and to practice within welfare state public institutions. As a result, doctors possessed all the key qualities of old and new professionalism. Among the qualities of the professionalism of medical practice, Parsons (2001, pp. 428-479) drew attention to: (i) a specialization in technical competence linked to the ability to develop a profession by differentiating these specialities; (ii) real compliance with the key service ideal deontological principles, which are: observance of professional secrecy and putting the patient's interest above the private interest of a specialist; (iii) the possibility of transferring peripheral practices to support staff; (iv) occupational monopoly for assessing the quality of medical services provided, (v) obligation to permanent improvement of professional competence in line with the increase in scientific medical knowledge; (vi) clearly defined the professional role of a doctor as a helper and the patient as a recipient of assistance.

The doctor's profession, in Parsons's analytical approach, allowed to link together not two - as Wilensky proposed - but three components of occupational professionalism: (1) objective scientific knowledge about effective help practices, (2) applied technique associated with the use of modern apparatus in service providing and (3) professional deontology protected by the occupational group itself. None other helping occupations has been able to achieve perfection simultaneously in these the three fields of professionalism. 
During the so-called golden age of welfare state $(50 \mathrm{~s}, 60 \mathrm{~s}$ and $70 \mathrm{~s}$ of the 20th century), helping specialities could only envy doctors and possibly develop in their vicinity as support staff (other medical professions) or supplementary staff (for years, social work was practised within this category).

The Parsons' helping professions model, which can be referred to as the $3 \mathrm{P}$ model (professional knowledge, professional technique, professional code of ethics), has been largely deconstructed in the last two decades of the 20th century by the cancer of the institutional crisis of welfare state. Two processes turned out to be crucial here: (1) deregulation and (2) deinstitutionalisation. At the same time, while the first process involved the launch of mechanisms for de-professionalising the helping semi-professions, the second process shifted the professionalisation process of to new tracks, somehow freeing professional helping practice from the grip of Parsons's institutionalised corset.

\section{The welfare states reconstruction:}

\section{helping professions on a deregulation and deinstitutionalisation path}

The leading theme of comparative social policy in the 1980s was the welfare state crisis (The Welfare State in Crisis 1981). Symptoms of the crisis were noticed already in the second half of the 1970s, but it was the governments of Margaret Thatcher in Great Britain and Ronald Reagan in the United States of the 1980s that purposely sought welfare state retrenchment (Pierson, 1996) and broke down the post-war consensus in social policy programming (Mishra, 1990, pp. 1-17). In the 1990s, market-oriented changes in developed western countries were associated with the rejection of communism in the countries of Central and Eastern Europe and jointly interpreted as the global expansion of the neoliberal approach (Jordan, 2010).

Analysis associated welfare state reconstruction with building the post-industrial social order (Esping-Andersen, 2000) or post-modern order (Mishra, 1993). The indisputable element of the change was the limitation of the role of the state; but interpretations of this process pointed to two structural beneficiaries: the market and civil society. In the first interpretation, the privatisation of welfare state was taking place (Le Grand \& Robinson, 1984a); in the second - the transformation from a welfare state to a welfare society (Rodger, 2000).

Both these directions of structural change had some common features going beyond the negative "rolling back of the activities of the state program" (Le Grand \& Robinson, 1984b, p. 3) and included the appreciation of efficient management of social services, the pursuit of individualisation of assistance and attaching greater importance to opinions of service users in relation to the specialist knowledge (Miller, 2004). To some extent, these two trends coexisted and overlapped with the privatisation and commercialisation trend dominating in the $1980 \mathrm{~s}$ and 1990s, and the socialising trend catching the proverbial wind in the sails in the first two decades of the 21st century. The result of the coexistence is the welfare pluralism model, where, in addition to public entities, market entities, civic sector organizations, family and informal sector entities are active producers of welfare (Ascoli \& Ranci, 2002b). 
At the same time, both currents of changes are based to a large extent on mutually alternative program assumptions. The difference in program assumptions is clearly visible in relation to helping professions and social services. The direction of privatisation of social services launched the process of de-professionalisation of welfare assistance, while the current of socialisation of social services favoured the processes of new professionalisation.

\section{Deregulation and deprofessionalisation}

The shift to privatisation and marketisation of social services should be understood broadly as a program of basic reconstruction of the foundations of welfare state:

"Privatisation (...) does not simply refer to a shift of physical goods to the private sector. Nor does it rest in the transfer of responsibilities form public to private (...). Rather, it includes an alteration in the nature of decision making. The creation of markets, rather than singlesource providers (...). Within this framework 'choicer' has been privatized - removed from the collective public domain, and the responsibility of private individuals." (Drakeford, 2000, p. 19).

In the normative aspect, the privatisation and marketisation trend referred to the assumed ideology of managerialism (Enteman, 1993, pp. 152-193). This ideology can be translated into four simple program slogans: (i) customers not clients, (ii) purchasers not providers; (iii) competition not allocation; (iv) equality of opportunity not equality of outcome (Drakeford, 2000, pp. 24-28). As part of the economic privatisation policy, the welfare state includes activities in four directions:

“a) The reduction of some public programmes, accompanied by an increase in the private provision of the same services;

b) The shift of ownership of some services from public or semi-public agencies to private auspices;

c) The development of policies involving public funding of private services;

d) The introduction of deregulation that has allowed private agencies to enter fields previously dominated by state monopolies." (Ascoli \& Ranci, 2002a, p. 6).

Ugo Ascoli and Cinstanzo Ranci (2002a, pp. 6-10) point to two privatisation models being implemented: demand-driven privatisation and supply-driven privatisation. The latter dominated the changes in the use of social services, and was described in the literature as a concept of quasi-markets (Le Grand \& Bartlett, 1993a; Bertlett et al., 1994). Leading theorists explained the essence of quasi-markets as follows:

"They are 'markets' because they replace monopolistic state providers with competitive independent ones. They are 'quasi' because they differ from conventional markets in a number of key ways. The differences are on both the supply and demand sides. On the supply side, as with conventional markets, there is competition between productive enterprises or service suppliers .... However, in contrast to conventional markets all these organisations are not necessarily out to maximize their profits ... on the demand side, consumer purchasing power is not expressed in money terms in a quasi-market." (Le Grand \& Bartlett, 1993b, p. 10). 
The most important operational assumptions of this concept are presented in Box 2.

Box 2. Features of a quasi market

- conceptualisation by Carl Propper, William Bartlett and Deborah Wilson

(1) "bureaucratic mechanisms of service delivery were replaced by competitive systems;

(2) separation of purchaser and provider functions within each service ... the introduction of formula funding of providers in some cases and the creation of a system of contracting between purchasers and providers in others;

(3) provision of services remains free at the point of delivery: no money changes hands the final user ... and the provider of services;

(4) providing services has been transferred from an integrated set of a state owned and managed enterprises to a variety of independent provider organisations including non-for-profit organisations, private companies and state owned units under devolved management".

Source: Propper et al., 1994, pp. 1-2.

The introduction of market mechanisms and managerialism to broadly understood social services led to deregulation welfare delivering. Deregulation meant changes at the legal level, enabling employees with lower competences and qualifications, but cheaper, to participate in providing assistance. At the same time, optimisation of resource management increased led to fragmentation of social services. This led to de-professionalisation, in accordance with Robert Merton's (1968, p. 618) observation that the fragmentation of activities causes the disappearance of public identification of the profession.

De-professionalisation of helping semi-professions was accurately described by John Harris (2003) on the example of social work, where it was manifested by:

- "reduc[ing] the power of welfare state professionals" (ibid., p. 39) and "substantial degree of autonomy and discretion as bureau-professionals" (ibid., p. 7),

- "development of management as a separate profession, leading to the suggestion that managers in social services did not a qualification in social work" (ibid., p. 57),

- "transformation of professionals into managers (...) social workers were to see themselves not as professionals but as care managers" (ibid., pp. 66-67),

- "the fragmentation of social work tasks and their redivision between qualified and lessqualified staff" (ibid., p. 76).

Two other effects should be mentioned: (i) promoting "quality rather than price competition" (Propper et al., 1994, p. 6), although the theoretical assumptions of the quasi-market concept were exactly the opposite; (ii) cream skimming practices (getting rid of clients who are difficult to work with - Matsaganios \& Glennerster, 1994) which undermined the deontological service ideal. As "any specific skills traditionally associated with social work seemed no longer to be highly valued" (Harris, 2003, p. 68), the status of social workers decreased to state technician, what Harris named as "McDonaldisation of the social work business" (ibid., pp. 75-76).

"New mode of marketised state provision" (Harris, 2003, p. 7) covered most of the welfare states infrastructure, including such various services as education services, 
health services, personal and social services, employment services, social housing, urban public transport, social and community care, social work (Le Grand \& Bartlett, 1993; Le Grand \& Robinson, 1984; McCarthy, 1989). Thus, the phenomenon of deregulation and de-professionalisation covered, to a greater or lesser extent, practically all helping semi-professions.

\section{Deinstitutionalisation and socialisation}

The second trend of welfare state reconstruction was associated with the appreciation of the role of civil society entities. The idea of social citizenship became a normative justification for this reform trend (Evers \& Guillemard, 2013). This idea refers to the concept of Thomas H. Marshall (1950), formulated in the mid-twentieth century, assuming that social rights constitute one of three - next to civil rights and political rights components of citizenship. The implementation of social rights was, in Marshall's view, a fundamental goal and also the legitimacy of welfare state established in Europe in the 20th century, as civil and political rights have become common on our continent before. At the turn of the 20th and 21st centuries, the idea of social citizenship appeared again (Bulmer \& Rees, 1996), but the renaissance of social citizenship was combined with social rights redefinition (Rymsza, 2013a, pp. 319-322). There has been a shift from old passive citizenship to new active citizenship (Evers \& Guillmard, 2013, pp. 4-8). In the active approach, the social dimension of citizenship was no longer associated with the access of citizens to social protection, but with the possibility of full, active participation in social life (Kaźmierczak, 2017). Active citizenship was positioned "beyond written rights and duties" (Evers \& Guillmard, 2013, p. 26) and associated with the development of civil society (Janoski, 1998). In other words, the pursuit of the implementation of active social citizenship meant not so much further development of public institutions of the welfare state infrastructure as the promotion of "culture of civility and civicness" (Evers \& Guillemard, 2013, p. 26).

The new approach provoked "turn to policies of social investments" (Evers \& Guillemard, 2013, p. 4), and the purpose of these investments was to strengthen all actors of collective life situating their activity outside the state and the market, i.e. in the area of core civil society and its "extensions" as family, cooperatives, mutual trusts, informal initiatives etc. (Deakin, 2001, p. 19). Public programs aimed at strengthening the potential of civil society and extracting the causative force of citizens have adopted the formulas: policies of activation and inclusion (van Berkel \& Møller, 2002). Helping professions implemented the activation services, with economic activation consisting in raising the employability of the unemployed coming to the fore. Employment services played a key role here (van Berkel et al., 2017), including the services of specialists such as career counsellors, job coaches and employment agents. But the activating approach also included non-economic aspects of social life - here, the trend of professional help defined as citizenship-based social work became active (van Ewijk, 2010). 
The empowerment approach became the key slogan of this trend (Trägardh \& Svewdberg, 2013), meaning profiling professional assistance so that dependent people regain control over their own lives and the ability to perform social roles. Activation frontline work was embedded in non-profit organizations as the so-called mediating structures capable of empowering the people (Berger \& Neuhaus, 1990). In this way, after years of domination by public services, social organizations again became the leading service delivery agencies (Harris \& Rochester, 2001).

Activation services have their strengths and weaknesses (Rymsza, 2013b, pp. 99-151). In fact, two activation models can be distinguished: the empowerment model and the underclass management model (Rymsza \& Karwacki, 2017); the first is the model that prefers the social inclusion of excluded people, based on social work provided by specialists employed in non-profit organizations; the second is a model based on employment services contracted, in accordance with the assumptions of new public management, under tender procedures mainly with for-profit agencies.

As part of the empowerment model, there was a renaissance of community work and community services (Taylor, 2011). Thanks to the new de-institutionalisation policy implemented in the European Union first of all in four areas of professional help: support for the disabled, environmental psychiatry, care for seniors and foster care, this trend of professional assistance has found a space for growth. Helping professions such as community workers, community organisers and community care delivers are dynamically developing within the community focused trend. The methodology of helping here combines (i) the empowerment approach with (ii) capacity building and strengthening social ties as elements of community work (Miller, 2004, pp. 209-229).

De-institutionalisation seems to set the main direction for the development of helping professions in 21st century Europe. We can define this direction as socialisation of social services. As part of it, new techniques for helping develop, but at the same time there is a return to the sources. It is worth bearing in mind that professional help was born before the emergence of welfare state and grew out of the tradition of social engagement (Frysztacki, 2019). The development of the welfare state infrastructure was conducive to the professionalisation of helping, especially in its technical dimension, but at the same time bureaucratised professional help. De-institutionalisation releases help from this bureaucratic corset and, at the same time - contrary to the deregulatory trend in social policy - focuses on the development of a professional assistance methods and techniques (Miller, 2004, pp. 83-84). It is just that it reformulates the framework of the helping relationship from a hierarchical system (where the specialist knows better) into a partnership relationship between professional helpers and service users. Social services are co-produced here by professional helpers and engaged citizens from strengthened communities. This does not mean de-professionalisation of support. Rather, a new space is emerging for the development of helping professions - not as part of welfare state, but as part of welfare society (Rodger, 2000). 


\section{Professionalisation of social work and other helping occupations in Poland after 1989}

The years 1989-2019 — three decades of systemic changes in Poland after half a century of communism - was a period that favoured the development of helping occupations. Because communism as a "longest path from capitalism to capitalism" (Roszkowski, 2019, p. 55) was a kind of a freezer for ideas and development processes, the period of modernisation of Poland and other countries of Central and Eastern Europe at the turn of the 20th and 21st centuries can be seen as resembling the development of Western Europe after the end of World War II - a three decades of the golden age of social policy (Esping-Andersen, 1996): as a time to create social well-being based on welfare mix infrastructure adapted to the conditions of free market economy, political democracy and the activity of civil society.

The three decades of the modernisation of Poland after communism can be divided into two periods. The first started with the partially free parliamentary elections on 4 June, 1989, and ended by Poland's accession to the European Union on 1 May, 2004. The dynamics of development processes in these years was determined by the logic of systemic change. During this period, national social policy was strongly influenced by neoliberal ideology, which translated into the dismantling of social infrastructure inherited from communism and focus on selective programs targeted at "losers of the reform process" (Rymsza, 2013a, pp. 311-315). The activity of Polish helping professions was also profiled towards selective protective measures.

The years 2005-2019 was a period of post-accession modernisation, when Poland, still making up for the backwardness caused by communism, was at the same time subject to the same development processes as the "old" EU-15 (Rymsza, 2013b, pp. 32-34). During this period, there was a successive departure from the neoliberal strategy. Under the influence of the EU agenda, the importance of public services, especially employment services, activation services and services promoting work-family balance had grown (Golinowska, 2013, pp. 23-26). After 2015, there was also an increase in universal cash benefits, the most vivid example of which is the Family 500 Plus Programme (Rymsza, 2018).

Narrowing the analysis of the meanderings of Polish social policy after 1989 to the issues of social services and helping professions, it is worth pointing out three development processes:

(1) developing a category of public trust professions including medical and psychological professions;

(2) emancipation of the profession of a social worker associated with the location of social work in the newly created institution of state social policy - social welfare;

(3) the emergence of a number of new assistance specialties and helping occupations in the absence of mechanisms for mutual positioning of old and new semi-professions. 


\section{Professions of public trust: Polish model of liberal professions}

In Poland, both aspects of professionalism: technical and normative are fully implemented by the professions of public trust. Professions of public trust are a specifically Polish conceptual category (Krasnowolski, 2013), which has constitutional legitimacy in the national legal order. Public trust professions are the professions with which statutory self-governments "shall concern themselves with the proper practice of such professions in accordance with, and for the purpose of protecting, the public interest" (Constitution of the Republic of Poland of 1997, art. 17.1.). The ethical requirement here covers the protection of the public interest, which is not the same as the service ideal in Wilensky's approach.

The Polish legislator regulated the functioning of self-governments of the following professions: lawyers, legal advisers, doctors and dentists, pharmacists, nurses and midwives, psychologists, physiotherapists, laboratory diagnostics, patent attorneys, architects, construction engineers and tax advisers. Thus, these and only these professions can be considered as public trust professions in Poland. The category of professions of public trust corresponds to the category of liberal professions established in European culture (Krasnowolski, 2013), which in turn are the progenitors of established professions in Carr-Saunders' terms.

Representatives of all Polish professions of public trust provide qualified services to citizens, taking into account the both dimensions of professionalism: technical and normative. Mostly, the services they provide are not included in the cumulative category of social services; such services can be considered as services provided by medical professionals and psychologists. Social services in Poland remain the domain of helping occupations, which in the vast majority do not belong to the category of professions of public trust. Although most of the helping occupations are in the process of professionalisation, they will probably not achieve the status of public trust professions. This is not Polish specificity. As already noted, in comparative literature, helping occupations fall into the category of semi-professions.

In the European Union, helping professions fall into the legal category of regulated occupations, i.e. those whose practice involves obtaining formal qualifications specified in national law (Krasnowolski, 2013). The EU category of regulated occupations increasingly penetrates the national legal orders of EU Member States, including Polish law, determining the formal status of professional helpers. In Poland, professional helpers as representatives of regulated occupations are situated in accordance with the semi-profession formula: halfway between professions of public trust and unregulated occupations.

The inclusion of medical professions in the category of professions of public trust meant that they were given prestige equal to legal professions in Poland. At the same time, their separation from other professional assistance activities meant that - unlike in Parson's approach - it was not the medical professions that were the benchmark for the development of contemporary helping semi-professions. For the same reason, 
psychological and psychotherapist circles in Poland maintain their distinctiveness from other helping semi-professions. Following 1989, attempts were made to make social work a reference category for professional helping practices in Poland (Rymsza, 2014b).

\section{Professionalisation through institutionalisation and education: development of social work}

Polish social work has rich traditions dating back to the turn of the 19th and 20th centuries and grows out of the practice of social work as a methodical impact on the local community (Wódz, 1998). The roots of Polish helping professions are not casework practices or clinical social work, but the tradition of social self-organization animated by local leaders (Rymsza, 2019). This strong community orientation corresponds to the tradition of social work in continental Europe (Frysztacki, 2008, p. 23). In the interwar period, Poland implemented the model of "socialised and localised care and social assistance" (Zalewski, 2005, p. 81) including numerous grass-rooted social and community work practices.

After World War II, professional assistance activities took the form of social care organized as part of the health care system (Zalewski, 2005, pp. 120-126), not because the profession of a doctor served as a model, but to "hide" poverty prevention measures, which problem did not officially exist in the communist system (Niesporek, 2019, pp. 524-525). Towards the end of communism, the trend of professionalisation of social care appeared in educational activities, whose output was the basis for institutional changes undertaken after the change of the system.

In 1990, social care was separated from the health care system and transformed into a social welfare system (Kozak, 2014) and this reorganization change was associated with a broader decentralisation reform - restitution of municipal self-governments (Krzyszkowski, 2005). One of the elements of the professionalisation of social assistance was the creation of job places for qualified social workers as representatives of the new helping profession. The qualification requirements for social workers were raised (in relation to the requirements previously set for social care workers): first it was the completion of higher education in social sciences, and since 2007 - in the field of social work (Szmagalski, 2012; Kromolicka, 2011). The Polish Association of Schools of Social Work played an important role in professionalisation through education (see Kromolicka \& Jarzębińska, 2017; Matyjas \& Porąbaniec, 2008).

The professionalisation of the social worker occupation was based on two pillars: (i) professionalisation through institutionalisation understood as the "process of developing new organizational structures" (Trawkowska, 2009, p. 123) and (ii) professionalisation through education understood as the "process of turning social work into a discipline" (Kantowicz, 2019, p. 77). The other three elements of professionalisation highlighted by Wilensky: (iii) building representation of the professional community, (iv) adopting separate regulations governing the activities of specialists in a given profession, and (v) creating their own code of professional ethics, although present, played a secondary 
role here. Established in 1987, the Polish Society of Social Workers (PSSW), despite a real impact on the creation of the framework of the new social welfare system (Szmagalski, 2019, pp. 555-556), did not obtain the status of a recognisable, representative occupational organisation, and ceased operations after they failed, in 2006, to convince the legislators to pass the Act on the profession of social worker. Currently, the organisation that integrates the occupational group of social workers employed in social welfare institutions is the Polish Federation of Social Workers and Social Service Employees Unions, which, however, focuses its activity on issues related to working conditions, and not on the professionalisation of competencies and practices related to providing assistance. Decrepitude of PSSW meant that the Code of Ethics adopted by that organization in 1998 has a relatively small impact on the professional practice of social workers.

Institutionalisation should be considered the dominant strategy for the professionalisation of social work in 1989-2019, since the process of its disciplinarisation stopped in a half of the way - social work became a university course, but efforts to recognize it as a separate scientific discipline in the field of social sciences were unsuccessful. Professionalisation through institutionalisation as a concept for the development of social work was a derivative of the broader social policy strategy of the state: building social welfare as a new segment of the social security system. In the period of transformation, this segment was intended to address the issue of providing protective measures limiting the social costs of economic reforms. Municipal social assistance centres (Polish acronym - OPS) have fulfilled well the function of "creation of a social safety net which replaces the 'guarantees' of communism" entrusted to them (Księżopolski, 2013, p. 40). However, this profile of OPS's activities led to far-reaching bureaucratisation of the occupation of social worker (Rymsza, 2013c). Social workers have become administrators for the distribution of cash benefits and in-kind assistance, and not social work specialists. Moreover, bureaucratisation meant that many social workers employed in OPS did not provide social work at all, and social work developed largely on the outskirts of the public social assistance system (Rymsza, 2014a, pp. 158-160) and in non-governmental organizations (Kromolicka, 2005).

To some extent, the Polish approach to the professionalisation of social work resembles the American approach described by Wilensky and Lebeaux (1965), and consisting in making social workers a collective agent of activities for social well-being. With one important difference. While American social work has become a broad brand of helpers including the assistance practices of professionals of various specialties employed in various institutions (DuBois \& Miley, 2014), in Poland social work was promoted as a single brand located in one specific institution - social welfare. As a consequence, when the role of social welfare facilities after transformation began to lose its significance, this resulted in a decrease in the prestige of social workers, and thus the strategy of professionalisation through institutionalisation exhausted its development potential (Kotlarska-Michalska, 2010). Currently, it has even become a dysfunctional strategy, as the social services development direction in the European Union is determined by the principle of de-institutionalisation (Krzyszkowski, 2019, pp. 210-211). 
Let us add that while the achievements of many schools and methodological trends in Poland were taken into account at the level of social work education, the institutional model adopted did not fit the Polish tradition of community work. It is therefore understandable that the ongoing renaissance of interest in community work is associated with placing new social initiatives outside social welfare institutions (Skrzypczak, 2015). It also activates the strategy of institutional reorganization of social welfare by opening its facilities to the local community (Skrzypczak, 2014). An implementation of the latter strategy is the legal possibility of transforming social assistance centres into social service centres from 2020 with the intention of addressing social services to all members of local communities and linking them with community organizing (Rymsza, 2020).

\section{Professionalisation by differentiation: from a multitude of practices to new helping professions}

In Parsons's view, development through differentiation is one of the important manifestations of professionalisation. The emergence of specialties in a given profession testifies to its vitality, the ability to collect and process the experience of social practice into an objectified knowledge about methods of helping. In Poland, numerous innovative helping methods emerged from the assistance practices accumulated in the years 19892019 (see Kromolicka \& Jarzębińska, 2017). Some of the new methods are legitimised as new specialties within already established helping semi-professions. Examples: community work treated as a form of social work with the local community (Niesporek, 2013) and senior assistance perceived as a modern format for the occupation of carer (Szweda-Lewandowska, 2018). However, some helpers using new methods of assistance aspire to the status of new semi-professions. Examples include social animation (Klimczak-Ziółek, 2007), family assistance (Krasiejko, 2011) and street pedagogy (Sokołowska, 2017). Some specialists operate in suspension, with an unspecified status and unspecified professional identity. For examples recovery assistants (supporting people with mental disorders and problems), reintegration instructors (conducting vocational reintegration courses within social integration centres), job coaches (supporting disabled people in the work environment) and occupational therapists (conducting therapy through the work of people with disabilities in occupational therapy workshops).

The emergence of new helping specialties is taking place in the conditions of farreaching fragmentation of social services and often cause strong tensions between specialists from various aid industries. Architects of new social welfare system failed to build such a position that social workers coordinate assistance activities carried out by helpers from other (than social welfare) support systems, such as activation of the unemployed or rehabilitation of the disabled (Rymsza, 2013b, pp. 348-355). There is also a lack of legal framework for partnership cooperation of various helping professions.

A particular development path is set by the development of profiled assistantships as services addressed to specific categories of vulnerable people and families. Family assistants, assistants of people with disabilities or assistants for the elderly operate under 
the social welfare system and according to the logic of institutionalisation, are treated not so much as new emerging assistance professions, but as supported task-forces towards social workers recognized as leading specialists in the field of social welfare. The situation of assistants is thus reminiscent of Parsons' positioning of medical-related professions as peripheral specialists relative to the profession of a medical doctor central for this group. The most visible is the tension between social workers and family assistants. The latter emphasize that family assistantship is fundamentally different from social work with the family, because it gives up the instruments of social control in favour of strictly assistance activities with a strong focus on families' empowerment (Krasiejko, 2016).

When discussing the process of differentiating helping professions, one cannot ignore the separate path of professionalisation of psychological assistance and therapeutic practices. Psychologists were able to: (i) maintain, as in the case of medicine and law, a uniform 5-year university course in psychology, without the possibility of completing a bachelor's degree as a vocational higher-education programme, and (ii) create a professional self-government, which results in including psychologists in the elite group of public trust professions. As a consequence, from the formal side, psychologists and psychotherapists are closer to the medical profession than to helping professions, which is expressed by the administrative supervision over their professional activity exercised by the Minister of Health.

However psychologists failed to maintain a monopoly on the provision of therapeutic services; hence there are no requirement to graduate in psychology in order to practise psychotherapy. Psychotherapists consider psychotherapy as a separate field of knowledge (also from psychology) (Mizerska et al., 2018, p. 9). The requirement to complete a 4-year post-graduate training in psychotherapy was introduced for practising psychotherapy (ibid., p. 19). Psychotherapeutic schools managed to establish a joint representation. Psychotherapy Council associating (as of 2020) 17 societies and centres representing various psychotherapeutic schools and all key psychotherapeutic orientations: individual, group, children and youth psychotherapy, family psychotherapy and marriages and couples psychotherapy (see ibid., pp. 11-15).

Tension between psychologists not involved in therapy and psychotherapists is not the only division in this group of professional helpers. The second division separates practitioners operating on the open commercialised market and practitioners employed in public support facilities or non-profit organizations. The latter are definitely closer to helping professions. A specific category of helping practices emerges from the intersection of both dividing lines: these are commercially oriented practices, but not involving therapeutic measures. Personal development services such as tutoring, coaching and mentoring are developing in this field (Lignar-Paczocha, 2018).

\section{Development perspectives of Polish helping professions}

Comparison of the development path that Polish helping occupations underwent after 1989 with the experiences of other developed countries in this field allows to formulate five general conclusions. 
First of all, as in many other countries, helping occupations have entered the path of professionalisation in Poland, obtaining the status of semi-professions, with rather illusory perspectives on achieving the status of new professions. In the European Union legal order, helping professions are included in the group of regulated occupations and as such their status in Poland as an EU member state seems to be a stable systemic solution.

Secondly, the medical and psychological professions have gained the highest status of public trust professions and largely develop according to their own trajectory. Only occupations and specialties that are peripheral to both these areas such as preventive healthcare and community nursing (in the area of health) as well as career counselling and family counselling (in the field of psychology) have built partnership relations with selected helping professions.

Thirdly, Poland implemented the strategy to professionalise social work as a central specialty for the category of professional helpers. This strategy has only been partially successful. Social workers have become recognizable helping specialists, who, however, did not gain high prestige either in the public opinion or among other professional communities of helpers. The main mistake was excessive concentration on the institutional matters associated with the decision to locate the core of social workers in one institution - social assistance centres (OPS), whose position and prestige decreased along with the growing social well-being after the period of shock therapy in the 1990s.

Fourthly, the accumulation of assistance practices at the level of academic reflection and the response of helpers to new needs and social problems have launched in Poland the processes of professionalisation through differentiation. New assistance specialties are emerging, some of which aspire to obtain the status of new helping semi-professions. Within the social welfare system, new specialties take the form of profiled assistants who find difficulties to enter the professional emancipation path. This creates tension, duplication of assistance practices and ambiguities in the distribution of responsibility between specialists.

Fifthly, the fragmentation of social services in organizational dimension overlaps with the diversity of assistance practices in Poland. This is a state of disorder that differs from the model solutions known from comparative studies. For example, France distinguishes itself by a multitude of helping professions, which, however, operate as part of an integrated system of supporting citizens and families. In the United States, on the other hand, social work is a brand bringing together numerous profiled assistance specialties.

In Poland, public policy should be implemented to create a new order of social services. An analysis of past experience does not allow us to assume that such order will emerge as a result of self-organizing activities. A package of the following "catalyst" activities seems to be optimal for the development of Polish helping professions:

(1) building helping professions as a joint brand of professional helpers. The history of the social work professionalisation clearly shows that self-organization, even supported by the state, of one particular helping occupation has limited potential. 
(2) developing social work as a general methodology for professional help, not reserved for a specific profession. This requires acceptance that not only social workers provide social work and that the experiences of various helping professions serve to develop a social work methodology.

(3) creating a legal framework for the cooperation of associations representing various helping professions as well as developing common deontology for professional assistance.

(4) integrating social services through appropriate organizational changes at the local level, which will facilitate functional collaboration of helping professions.

The author of this study was involved as an expert in programming activities aimed at implementing elements of the presented package of public activities. In 2015-2017 he moderated a series of seminars and conferences co-organized by the Social Work Section of the Polish Sociological Society "Social work and old and new helping professions: mutual positioning and building a common identity of helping professions". In 2017-2019 he managed the merit work of the National Development Council and the Chancellery of the President of the Republic of Poland on solutions contained in the Act of 19 July 2019 on the implementation of social services by a social services centre (DzU 2019, item 1818), which creates conditions for the integration of social services. He also participated in the policy work of two congresses organized by the Chancellery of the President of the Republic of Poland: (i) the Counselling Congress (July 1, 2019) and the Congress of Helping Professions and Occupations (February 25, 2020), at which preliminary work on the concept of integrating helping professions was undertaken. The author expresses the hope that in the coming years in Poland both social services and helping professions become integrated which results in creating a new order in the area of professional assistance.

\section{References}

Ascoli, U. \& Ranci, C. (2002a). The Context of New Social Policies in Europe. In U. Ascoli, C. Ranci (eds), Dilemmas of the Welfare Mix. Kluwer Academic \& Plenum Publishers. Ascoli, U. \& Ranci, C. (eds) (2002b). Dilemmas of the Welfare Mix. Kluwer Academic \& Plenum Publishers.

Barber, B. (1963). Some Problems in The Sociology of The Professions. Daedalus.

Barber, B. (1965). The Sociology of Professions. In K. S. Lynn (ed.), The Professions in America. The Riverside Press.

Bartlett, W., Propper, C., Wilson, D., Le Grand, J. (eds) (1994). Quasi-markets in the Welfare State. SAUS Publications.

Barry, N. (1999). Welfare. Open University Press.

Berger, P., Neuhaus, R. (1990). To Empower People: The Role of Mediating Structures in Public Policy. American Enterprise Institute. 
Bertilsson, M. (1990). The welfare state, the professions and citizens. In R. Torstendahl, M. Burrage (eds), The Formation of Professions. Sage.

Bulmer, M. \& Rees A. M. (eds) (1996). Citizenship Today. UCL Press.

Carr-Saunders, A. M. (1955). Metropolitan Conditions and Traditional Professional Relationships. In R. M. Fisher (ed.), The Metropolis in Modern Life. Russel \& Russel.

Collins, R. (1990). Changing conceptions in the sociology of professions. In R. Torstendahl, M. Burrage (eds), The Formation of Professions., Sage.

Daniels, A. K. (1973). How Free should Professions Be. In E. Freidson (ed.), The Professions and Their Prospects. Sage.

Deakin, N. (2001). In Search of Civil Society. Palgrave.

Drakeford, M. (2000). Privatisation and Social Policy. Longman \& Pearson.

DuBois, B. \& Miley K.K. (2014). Social Work. An Empowering Profession. Pearson.

Durkheim, E. (1960). The Division of Labor in Society. The Free Press of Glencoe.

Engel, G. V. \& Hall, R. H. (1973). The Growing Industrialization of the Professions. In E. Freidson (ed.), The Professions and Their Prospects. Sage.

Enteman, W. F. (1993). Managerialism. The University of Wisconsin Press.

Esping-Andersen, G. (1996). After the Golden Age? Welfare State Dilemmas in a Global Economy. In G. Esping-Andersen (ed.), Welfare State in Transition. Sage.

Esping-Andersen, G. (2000). Social Foundations of Postindustrial Economies. Oxford University Press.

Etzioni, A. (1969). Preface. In A. Etzioni (ed.), The Semi-Professions and Their Organization. The Free Press.

Evers, A. \& Guillemard, A.-M. (2013). Introduction: Marshall's Concept of Citizenship and Contenporary Welfare Reconfiguration. In A. Evers, A.-M. Guillemard (eds), Social Policy and Citizenship. Oxford University Press.

Frysztacki, K. (2008). Siła i słabość procesów profesjonalizacji pracy socjalnej (z europejsko-amerykańskim pierwiastkiem porównawczym). In B. Matyjas, M. Porąbaniec (eds), $W$ drodze ku profesjonalizacji zawodu pracownika socjalnego. Wydawnictwo Akademii Świętokrzyskiej.

Frysztacki, K. (2019). Wokót pracy socjalnej. Od koncepcji i teorii do kontekstów empiryczno-aplikacyjnych. Wydawnictwo UJ.

Fuller, R. \& Myers, R. (1941). The Natural History of a Social Problem. American Sociological Review, 6(3).

George, V. \& Wilding P. (1992). Ideology and Social Welfare. Routledge.

Golinowska, S. (2013). The Polish Welfare State Birth and Twilight? In P. Michoń, J. Orczyk, M. Żukowski (eds), Facing the Challenges. Social Policy in Poland after 1990. Poznań University of Economics Press.

Goode, W. J. (1969). The Theoretical Limits of Professionalization. In A. Etzioni (ed.), The Semi-Professions and Their Organization. The Free Press.

Goodin, R. E. (1988). Reasons for Welfare. Princeton University Press.

Greenwood, E. (1957). Attributes of a Profession. Social Work, 2(3).

Harris, J. (2003). The Social Work Business. Routledge. 
Harris, M. \& Rochester, C. (eds) (2001). Voluntary Organisations and Social Policy in Britain. Palgrave.

Janoski, T. (1998). Citizenship and Civil Society. Cambridge University Press.

Johnson, T. J. (1972). Professions and Power. Macmillan.

Jordan, B. (2010). What's Wrong with Social Policy and How to Fix it. Polity Press.

Kaczyńska, W. (ed.) (2010). O etyce stużb spotecznych. Uniwersytet Warszawski.

Kantowicz, E. (2000). Wybrane koncepcje i standardy kształcenia do profesji społecznych w Europie. In E. Marynowicz-Hetka, A. Wagner, J. Piekarski (eds), Profesje spoteczne $w$ Europie. Śląsk.

Kantowicz, E. (2019). Praca socjalna w interdyscyplinarnym splocie nauk społecznych. In K. Frysztacki (ed.), Praca socjalna. 30 wyktadów. PWN.

Kaźmierczak, T. (2017). Aktywne obywatelstwo: o jego uwarunkowaniach i janusowym obliczu. In A. Karwacki et al., Niezatrudnieniowe wymiary aktywizacji. Wydawnictwo Naukowe UMK.

Klimczak-Ziółek, J. (2007). Animacja społeczna w teorii i praktyce. Wybrane zagadnienia. In S. Pawlas-Czyż (ed.), Praca socjalna wobec wspótczesnych problemów spotecznych. Akapit.

Kotlarska-Michalska, A. (2010). Przejawy dysfunkcji w pomocy społecznej i możliwości ich naprawy. Problemy Polityki Społecznej. Studia i Dyskusje, 13-14.

Kozak, M. (2014). Development of social services in Poland after 1989: a practical perspective. In M. Rymsza (ed.), Toward Active Welfare. Institute of Public Affairs.

Krasiejko, I. (2011). Nowa rola asystenta rodziny. In D. Trawkowska (ed.), Pomoc spoteczna wobec rodzin. Akapit.

Krasiejko, I. (2016). Asystentura rodziny. Rekomendacje metodyczne i organizacyjne. Ministerstwo Rodziny, Pracy i Polityki Społecznej.

Krasnowolski, A. (2013). Zawody zaufania publicznego, zawody regulowane oraz wolne zawody. Geneza, funkcjonowanie i aktualne problemy. Kancelaria Senatu.

Kromolicka, B. (ed.) (2005). Praca socjalna w organizacjach pozarzadowych. Akapit.

Kromolicka B. (2011). Kształcenie do pracy socjalnej w Polsce — praktyka codzienności. In K. Piątek, K. Szymańska-Zybertowicz (eds), Profesjonalna praca socjalna. Nowy paradygmat czy niedokończone zadanie? Akapit.

Kromolicka, B. \& Jarzębińska A. (eds) (2017). O (wyzwaniach) wspótczesnej pracy socjalnej. Uniwersytet Szczeciński.

Krzyszkowski, J. (2005). Między państwem opiekuńczym a opiekuńczym społeczeństwem. Wydawnictwo Uniwersytetu Łódzkiego.

Krzyszkowski, J. (2019). Ewolucja publicznej pomocy społecznej w Polsce. In K. Frysztacki (ed.), Praca socjalna. 30 wyktadów. PWN.

Księżopolski, M. (2013). In Search of a New Post-Socialist Social Policy Model in Poland. In P. Michoń, J. Orczyk, M. Żukowski (eds.), Facing the Challenges. Social Policy in Poland after 1990. Poznań University of Economics Press.

Le Grand, J. \& Robinson, R. (eds) (1984a). Privatisation and the Welfare State. George Allen \& Unwin. 
Le Grand, J. \& Robinson, R. (1984b). Privatisation and the Welfare State: An Introduction. In J. Le Grand, R. Robinson (eds), Privatisation and the Welfare State. George Allen \& Unwin.

Le Grand, J. \& Bartlett, W. (eds) (1993a). Quasi-Markets and Social Policy. The Macmillan Press.

Le Grand, J. \& Bartlett, W. (1993b). Introduction. In J. Le Grand, W. Barlett (eds), Quasi-Markets and Social Policy. The Macmillan Press.

Lignar-Paczocha, K. (2018). Coaching w organizacjach pozarzadowych - wybrane zagadnienia i pogtębiona perspektywa coachów. Kwartalnik Trzeci Sektor, 41.

Łuczyńska, M. (2013). Pracownicy socjalni w procesie profesjonalizacji. Instytut Spraw Publicznych.

Marshall, T. H. (1950). Citizenship and social class and other essays. Cambridge University Press.

Matsaganis, M. \& Glennerster, H. (1994). Cream-skimming and fundholding. In W. Bartlett, C. Propper, D. Wilson, J. Le Grand (eds), Quasi-markets in the Welfare State. SAUS Publications.

Matyjas, B. \& Porąbaniec M. (eds) (2008). W drodze ku profesjonalizacji zawodu pracownika socjalnego. Wydawnictwo Akademii Świętokrzyskiej.

McCarthy, M. (ed.) (1989). The New Politics of Welfare. An Agenda for the 1990s? Macmillan.

Merton, R. K. (1968). Social Theory and Social Structure. The Free Press.

Miller, C. (2004). Producing Welfare. Palgrave Macmillan.

Ming-Cheng, L. (2005). The Professions: Prodigal Daughters of Modernity. In J. Adams, E. Clemens, A. S. Orloff (eds), Remaking Modernity: Politics, History, and Sociology. Duke University Press.

Mishra, R. (1981). Society and Social Policy. Macmillan.

Mishra, R. (1990). The Welfare State in Capitalist Society. Harvester Wheatsheaf.

Mishra, R. (1993). Social Policy in the post-modern word. In C. Jones (ed.), New Perspectives on the Welfare State in Europe. Routledge.

Mizerska, R., Pinkowska-Zielińskla, H., Jankiewicz, A., Modrzyńska, D., Kostrzewski, M., Wojtysiak, S. (2018). Psychoterapia. Vademecum. Polska Rada Psychoterapii.

Morel, N. (2010). Social Services. In T. Fizpatrick et al. (eds), International Encyclopedia of Social Work. Routledge.

Niesporek, A. (2013). Organizowanie spoteczności lokalnej. WSP im. J. Korczaka w Warszawie.

Niesporek, A. (2019). Edukacja w zakresie pracy socjalnej. In K. Frysztacki (ed.), Praca socjalna. 30 wyktadów. PWN.

Parsons, T. (2001). The Social System. Routledge.

Pinker, R. (1979). The Idea of Welfare. Heinemann.

Pierson, P. (1996). Dismantling the Welfare State? Cambridge University Press.

Propper, Z., Bartlett, W., Wilson, D., Introduction. In W. Bartlett et al. (eds) (1994). Quasi-markets in the Welfare State. SAUS. 
Rodger, J. J. (2000). From a Welfare State to a Welfare Society. Macmillan.

Roszkowski, W. (2019). Roztrzaskane lustro. Upadek cywilizacji zachodniej. Biały Kruk.

Rymsza, M. (2013a). The Two Decades of Social Policy in Poland: From Protection to

Activation of Citizens. In A. Evers, A.-M. Guillemard (eds), Social Policy and Citizenship. Oxford University Press.

Rymsza, M. (2013b). Aktywizacja w polityce spotecznej. Wydawnictwo IFiS PAN.

Rymsza, M. (2013c). Social Work and Social Workers in Poland. In P. Michoń, J. Orczyk, M. Żukowski (eds), Facing the Challenges. Social Policy in Poland after 1990. Poznań University of Economics Press.

Rymsza, M. (2014a). Social work in the Polish welfare system: between bureaucratization and professionalization. In M. Rymsza (ed.), Toward Active Welfare. Institute of Public Affairs.

Rymsza, M. (2014b). Pracownicy socjalni, służby społeczne — profesjonalizacja i rozwój zawodowy. Polityka Społeczna, 3.

Rymsza, M. (2018). Investing in Children as a public good: the example of the Family $500+$ Programme. In P. Bunio-Mroczek, J. Grotowska-Leder (eds), Investing in Children. University of Łódź.

Rymsza, M. (2019). Polska tradycja społeczno-socjalna. In K. Frysztacki (ed.), Praca socjalna. 30 wyktadów. PWN.

Rymsza, M. (2020). Dlaczego centrum ustug spotecznych? Kancelaria Prezydenta RP (in printing).

Rymsza, M. \& Karwacki, A. (2017). Między podejściem empowerment a zarządzaniem underclass. Dwa modele aktywizacji w polityce społecznej. In A. Karwacki et al., Niezatrudnieniowe wymiary aktywizacji. Wydawnictwo Naukowe UMK.

Skrzypczak, B. (2014). W kierunku społecznościowej pracy socjalnej. Centrum Wspierania Aktywności Lokalnej CAL.

Skrzypczak, B. (2015). (Proto)instytucje społecznościowe — przejawy i formy deinstytucjonalizacji aktywności obywatelskiej i społecznej. In R. Krenz, S. Mocek B. Skrzypczak (eds), Efekt motyla. Collegium Civitas.

Sokołowska J. (2017). Pedagogika ulicy jako edukacja do przekraczania granic. In B. Kromolicka, A. Jarzębińska (eds), O (wyzwaniach) wspótczesnej pracy socjalnej. Uniwersytet Szczeciński.

Szatur-Jaworska B., (2010). Stużba społeczna, stużby spoteczne - spojrzenie multidyscyplinarne, in: B.Szatur-Jaworska, Służba społeczna, służby społeczne -spojrzenie multidyscyplinarne in: W. Kaczyńska (red.), O etyce stużb społecznych, IPSiR Uniwersytet Warszawski, Warszawa.

Szmagalski J. (2012). Kształcenie do pracy socjalnej w Polsce po 1989 roku. In M. Rymsza (ed.), Pracownicy socjalni i praca socjalna w Polsce. Instytut Spraw Publicznych.

Szmagalski, J. (2019). Ustawowy status, zobowiązania i ryzyka zawodowe pracowników socjalnych. In K. Frysztacki (ed.), Praca socjalna. 30 wyktadów. PWN.

Szweda-Lewandowska, Z. (2018). Opieka nad osobami starszymi. Wspierajacy $i$ wspierani. Wydawnictwo Uniwersytetu Łódzkiego. 
Taylor, M. (2011). Public Policy in the Community. Palgrave Macmillan.

The Welfare State in Crisis, OECD (1981). Paris.

Toren, N. (1969). Semi-Professionalism and Social Work. A Theoretical Perspective. In A. Etzioni (ed.), The Semi-Professions and Their Organization. The Free Press.

Trägardh, L. \& Svewdberg L. (2013). The Iron Law of Rights: Citizenship and Individual Empowerment in Modern Sweden. In A. Evers, A.-M. Guillemard (eds), Social Policy and Citizenship. Oxford University Press.

Trawkowska, D. (2009). Profesjonalizm w pracy socjalnej - perspektywa teoretyczna i empiryczna polskich doświadczeń. In W. Szymczak (ed.), Wspótczesne wyzwania $i$ metody pracy socjalnej. Towarzystwo Naukowe KUL \& KUL im. Jana Pawła II.

van Berkel, R. \& Møller, I. H. (eds) (2002). Active social policies in the EU. The Policy Press.

van Berkel, R., Caswell, D., Kupka, P., Larsen, F. (eds) (2017). Frontline Delivery of Welfare-to-Work Policies in Europe. Routledge.

van Ewijk, H. (2010). European Social Policy and Social Work. Routledge.

Warham, J. (1970). Social Policy in Context. Batsford.

Wilding, P. (2010). Welfare. In T. Fizpatrick et al. (eds), International Encyclopedia of Social Work. Routledge.

Wilensky, H. L. (1964). The Professionalization of Everyone? The American Journal of Sociology 2, vol. LXX.

Wilensky, H. L. \& Lebeaux, C. N. (1965). Industrial Society and Social Welfare. The Free Press.

Wódz, K. (1998). Praca socjalna w środowisku zamieszkania. Śląsk.

Zalewski, D. (2005). Opieka i pomoc spoteczna. Wydawnictwo UW. 